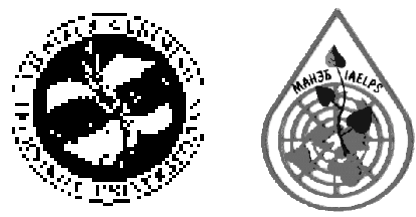

\title{
INVESTIGATION AND EVALUATION OF LANDFILL LEACHATE PERMEABILITY IN THE SOIL
}

\author{
Saulius Vasarevičius ${ }^{1}$, Jelena Čegariova ${ }^{1}$, Danutė Sližyte் ${ }^{2}$ \\ ${ }^{1}$ Dept of Environmental Protection, Vilnius Gediminas Technical University, \\ Sauletekio al. 11, LT-10223 Vilnius-40,Lithuania.E-mail: aai@ap.vtu.lt \\ ${ }^{2}$ Dept of Geotechnical Engineering, Vilnius Gediminas Technical University, \\ Sauletekio al. 11, LT-10223 Vilnius-40, Lithuania. E-mail: danute@st.vtu.lt
}

Received 22 May 2005; accepted 20 Jun 2005

\begin{abstract}
Today waste management is one of the most important environmental problems, danger that used landfills and their collected leachate can cause. This paper analyses the filtration coefficient of soils typical of landfill assessment by air conditions and different density of soils. Heavy metal concentrations were determined by using the flame absorption spectrometric method. Besides, the results of modeling heavy metal permeability are presented here. Dependence of heavy metal permeability characteristics on soil density are described. Experimental investigation and modeling of heavy metal permeability in the soil allowed us to determine that the least permeable soil is dusty sandy grit.
\end{abstract}

Keywords: landfill, leachate, filtration coefficient, flame absorption spectrometric method.

\section{Introduction}

Earlier there was no problem with waste because the population was not large and there was enough territory for waste to depose. But even in the ancient times people tried to recycle waste into fuel and fertilizers [1].

People seeked for a better life, and this was the reason for increase of economic and technological inventions. Despite that waste problems became urgent. It is necessary to analyse the flux of waste materials and evaluate direct technology development in waste management.

There is a tendency for natural resources to decrease and pollution and waste amount to increase. People started using synthetic materials - polyethylene, polyvinylchloride, polypropylene, pesticide etc. Chemical agents - different detergents, lacquers, paints, and pigments - are widely used. Manufacturing and application of the mentioned products stimulates the amount of waste to increase and pollutes the environment for long periods of time because synthetic materials have a long decomposition period.

Wrong ways of waste management can cause water and atmosphere pollution. For example, the waste leachate of an inappropriately designed landfill contaminates surface water as well as ground water. The great- est problem that is associated with waste management is lack of space in the existing landfills. The geological and environmental control approach shows that it's not so simple to find other places for landfills. Special attention should be paid to waste management in large cities because the amount of municipal waste increases every year. [2, 3] The mentioned facts influence increase in the number of landfills near settled areas. These territories may cause very harmful results for a surrounding environment as well as human health. One of the greatest menaces in landfills is leachate. It penetrates into the soil and pollutes soil and ground water. It is necessary to apply all known remedies to avoid the harm.

Lithuania has joined the European Union, its waste management system must be reorganized to fit the European Union requirements. Recently projects were prepared for municipal waste landfills that fit the European Union requirements to be established in Lithuanian regions.

The main goals of this work were:

- to examine dependence of the soil (medium coarse sand, sand with organic, peat, fine sand, dusty sandy grit) filtration coefficient upon temperature and soil density;

- to evaluate the soil filtration coefficient at the same density and temperature; 
- to examine heavy metal concentration in the leachate of municipal waste landfills;

- $\quad$ to simulate the leachate heavy metal scatter in the soil by using the obtained results.

\section{Methodology}

Soils typical of landfills were used in the experiment. Leachate was taken from a leachate collection trench in Kairiai Landfill in Šauliai region. Trenches are not immune to water and melting snow, so leachate naturally mixed with water was used in the experiment. Leachate contains many noxious materials that penetrate into deeper layers of the soil together with water. The aim of the investigation was to determine the filtration characteristics of different soils and to show a potential harm that could be done to the upper and deeper layers of the soil. The following soils were used during the experiment: 1) medium coarse sand; 2) sand with organics; 3) dusty sandy grit; 4) peat; 5) fine sand.

The aim of the experiment was:

- to determine dependence of the filtration coefficient upon temperature $\left(0{ }^{\circ} \mathrm{C}, 5{ }^{\circ} \mathrm{C}, 15^{\circ} \mathrm{C}\right.$, $\left.20{ }^{\circ} \mathrm{C}\right)$

- to determine dependence of the filtration coefficient upon the soil density;

- to compare the filtration coefficient of all the chosen soils of the same density.

The instruments used were:

An apparatus KF-OOM is presented in Fig 1; a stopwatch or a watch with the second hand; a vessel with water; a thermometer.

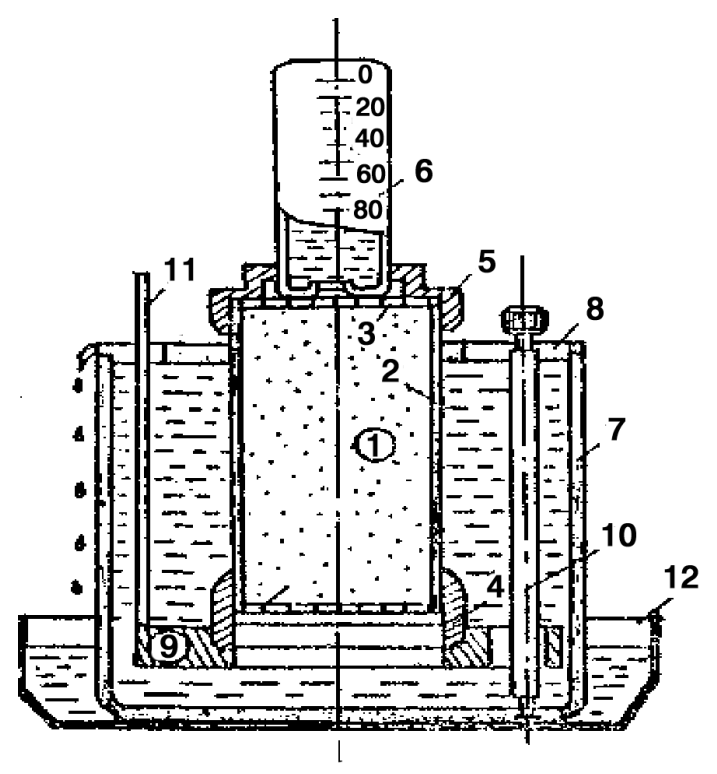

Fig 1. Principal diagram of apparatus KF-OOM: 1 - sand sample; 2 - metal tube; 3 - brass net (at the top and bottom); 4 - bottom ring (plastic); 5 - top ring (plastic); 6 - glass vessel with graded from 0 till 100; 7 equipment case; 8 - top case lid; 9 - moving ring; 10 bolt; 11 - rod with hydraulic incline graded from 0 to 1 ; 12 - bath
The equipment KF-OOM was used to study the filtration characteristics of sand. KF-OOM consists of three separate parts. The first part - a $100 \mathrm{~mm}$ high metal tube with brass netting and plastic rings on the both ends, with diameter of $56,5 \mathrm{~mm}$ and its transverse section area is $25 \mathrm{~cm}^{2}$. The second part - a glass-made vessel was used to determine the volume of filtrated water. The third part - a plastic case with measures to regulate and measure the hydraulic incline. We could study the sand filtration characteristics with this apparatus when the hydraulic incline, the size of which can be from 0 to 1,0 , is constant.

The experiment was conducted according to the method described in $[4,5]$.

The filtration coefficient value was calculated by an equation:

$$
k=V_{w} / t A I, \mathrm{~cm} / \mathrm{s},
$$

where

$V_{w}$ - volume of water $\mathrm{cm}^{3}$, filtered in time $t, s$;

$A=25 \mathrm{~cm}^{2}-$ diameter of soil sample, equal to the diameter of the metal tube;

$I$ - hydraulic incline.

The value of the filtration coefficient depends on the water temperature. We determined the filtration coefficient of the soil when the temperature was $15^{\circ} \mathrm{C}$, $10{ }^{\circ} \mathrm{C}$ and $0^{\circ} \mathrm{C}$. In this case the filtration coefficient was evaluated by an equation:

$$
k_{o C}=k / \eta, \mathrm{cm} / \mathrm{s} \text {, }
$$

where

$\eta$ - temperature correction; it was calculated by an equation:

$$
\eta=0,7+0,03 \mathrm{t}^{\circ}
$$

where

$\mathrm{t}^{\circ}$ - filtrate temperature.

We also used another dimension of the filtration coefficient $(k)-\mathrm{m} / 24 \mathrm{~h}$ in calculations. In this case the filtration coefficient in $\mathrm{cm} / \mathrm{s}$ was multiplied by 864 [6-8]:

$$
k_{o C}[\mathrm{~m} / 24 \mathrm{~h}]=864 k_{o C}, \mathrm{~cm} / \mathrm{s} .
$$

\section{Investigation results}

Dependence of the medium coarse sand filtration on temperature is given in Figs 2-7.

As we can see from Fig 2, the filtration coefficient changes, depending upon temperature. The filtration coefficient decreases with temperature. When the temperature decreased by 10 degrees from $15{ }^{\circ} \mathrm{C}$ to $5{ }^{\circ} \mathrm{C}$, the filtration coefficient decreased by $4 \%$. When the temperature of leachate decreased to $0{ }^{\circ} \mathrm{C}$, the filtration coefficient decreased by $5,1 \%$. The total filtration coefficient change was $9,1 \%$.

Calculation of the filtration coefficient of sand with organics and its dependence upon temperature

Fig 3 shows that when the temperature fell to $5{ }^{\circ} \mathrm{C}$, 


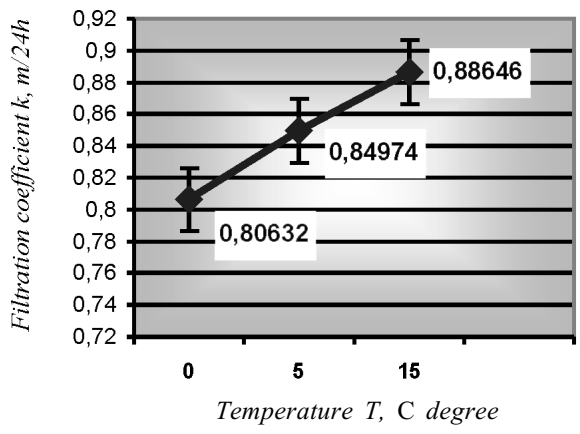

Fig 2. Dependence of medium coarse sand filtration coefficient upon temperature

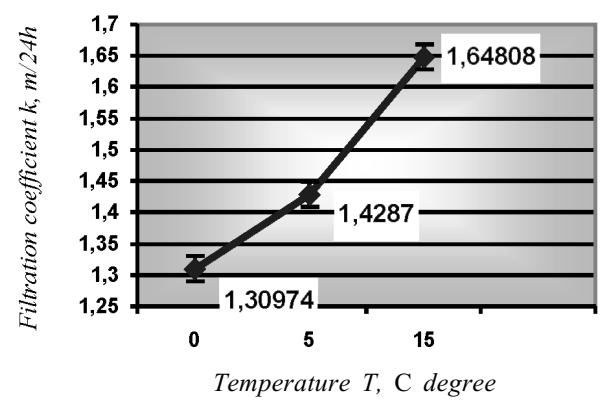

Fig 3. Dependence of sand with organics filtration coefficient upon temperature

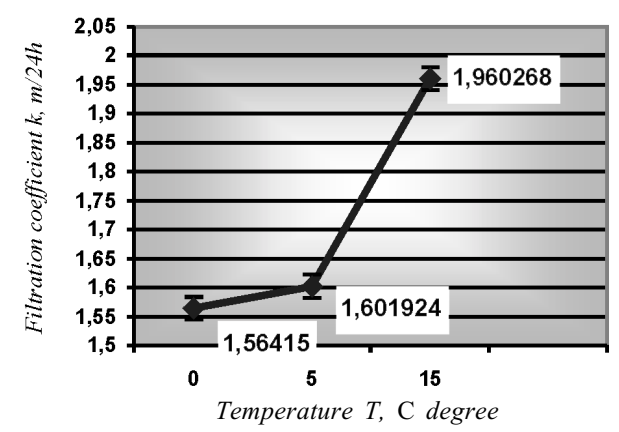

Fig 4. Dependence of peat filtration coefficient upon temperature

the filtration coefficient declined by $13,3 \%$, and when the temperature reached $0{ }^{\circ} \mathrm{C}$, it declined additionally by $8,3 \%$. The general moderation of the filtration coefficient of sand with organics was $21,6 \%$.

Calculation of the peat filtration coefficient and its dependence upon temperature

Peat was the next soil that was analysed.

In Fig 4 we can see a great difference between $15^{\circ} \mathrm{C}$ and $5^{\circ} \mathrm{C}$. This means that the filtration coefficient declined by $18,3 \%$, and after reaching $0{ }^{\circ} \mathrm{C}$, the filtration coefficient decreased more by $2,4 \%$.

Calculation of the fine sand filtration coefficient and its dependence upon temperature

Dependence of the fine sand filtration coefficient upon temperature and its change is shown in Fig 5.

Like in other soils the fine sand filtration coeffi-

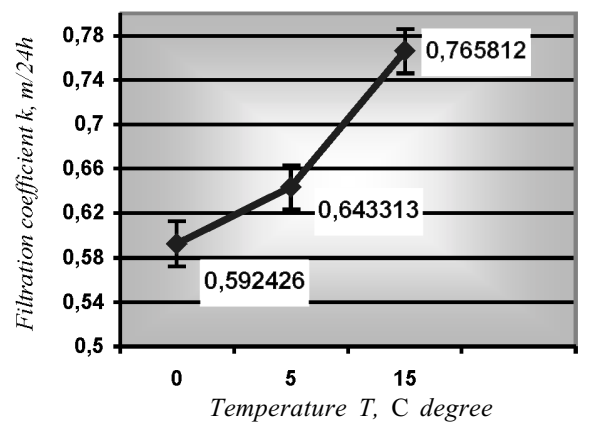

Fig 5. Dependence of fine sand filtration coefficient upon temperature

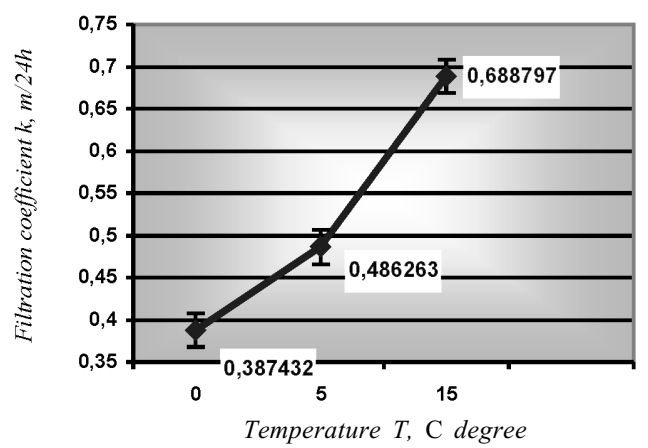

Fig 6. Dependence of dusty sandy grit upon temperature

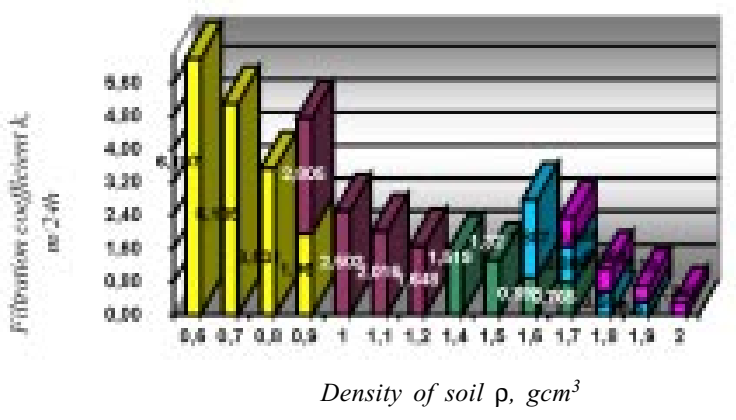

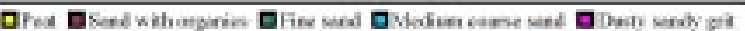

Fig 7. Dependence of soil filtration coefficient upon density

cient declined with the temperature down to $5{ }^{\circ} \mathrm{C}$, it declined by about $16 \%$, and when the temperature reached $0{ }^{\circ} \mathrm{C}$, the filtration coefficient decreased more by $8 \%$.

Calculation of the dusty sandy grit filtration coefficient and its dependence upon temperature

According to the results of the last experiment a conclusion could be made that the filtration coefficient of dusty sandy grit is the lowest compared with the other soils (the density of soil was not evaluated). This is because of the dusty fraction in the soil. The results of the experiment are given in Fig 6.

Like in other soils a maximum decline of the filtration coefficient was reached, when the temperature was $5{ }^{\circ} \mathrm{C}$. In this case it declined by $30 \%$. The filtration coefficient declined more by $20 \%$, when the experiment 
Table 1. Dependence of soil filtration qualities upon density

\begin{tabular}{|c|c|c|c|c|c|c|c|c|c|}
\hline \multicolumn{2}{|c|}{ Medium coarse sand } & \multicolumn{2}{c|}{ Sand with organics } & \multicolumn{2}{c|}{ Peat } & \multicolumn{2}{c|}{ Fine sand } & \multicolumn{2}{c|}{ Dusty sandy grit } \\
\hline $\begin{array}{c}\text { Density } \rho, \\
\mathrm{g} / \mathrm{cm}^{3}\end{array}$ & $k, \mathrm{~m} / 24 \mathrm{~h}$ & $\begin{array}{c}\text { Density } \rho, \\
\mathrm{g} / \mathrm{cm}^{3}\end{array}$ & $k, \mathrm{~m} / 24 \mathrm{~h}$ & $\begin{array}{c}\text { Density } \rho, \\
\mathrm{g} / \mathrm{cm}^{3}\end{array}$ & $k, \mathrm{~m} / 24 \mathrm{~h}$ & $\begin{array}{c}\text { Density } \rho, \\
\mathrm{g} / \mathrm{cm}^{3}\end{array}$ & $\mathrm{k}, \mathrm{m} / 24 \mathrm{~h}$ & $\begin{array}{c}\text { Density } \rho, \\
\mathrm{g} / \mathrm{cm}^{3}\end{array}$ & \begin{tabular}{c}
$\mathrm{k}, \mathrm{m} / 24 \mathrm{~h}$ \\
\hline 1,6
\end{tabular} \\
\hline 1,88738 & 0,9 & 2,80556 & 0,6 & 6,19786 & 1,4 & 1,51961 & 1,7 & 0,68880 \\
\hline 1,7 & 0,88646 & 1,0 & 2,50357 & 0,7 & 5,10564 & 1,5 & 1,32055 & 1,8 & 0,56448 \\
\hline 1,8 & 0,55471 & 1,1 & 2,01655 & 0,8 & 3,53188 & 1,6 & 0,89873 & 1,9 & 0,38072 \\
\hline 1,9 & 0,31182 & 1,2 & 1,64808 & 0,9 & 1,96027 & 1,7 & 0,76581 & 2,0 & 0,26240 \\
\hline
\end{tabular}

was done at a temperature of $0{ }^{\circ} \mathrm{C}$. According to the experimental results, we can say that the filtration coefficient of dusty sand grit at $0{ }^{\circ} \mathrm{C}$ is by $50 \%$ lower than that at $15{ }^{\circ} \mathrm{C}$. density

Calculation of the soil filtration dependence on

The following step of this investigation was to analyse the soil filtration qualities at different soil densities. These experiments were conducted at a temperature of $15{ }^{\circ} \mathrm{C}$ (Table 1$)$.

The results are given in a diagram for an easier interpretation. Fig 7 shows the filtration coefficient change for all the studied soils that depends on density. We managed to reach the same density only for some of the soils in order to compare the filtration qualities of soils during the experiment.

For example, when the density of peat and sand with organics is equal to $0,9 \mathrm{~g} / \mathrm{cm}^{3}$, the filtration coefficient of sand with organics is 1,4 times larger than that of peat. The filtration coefficient of medium coarse sand is 2,1 times larger than that of fine sand, when the density is $1,6 \mathrm{~g} / \mathrm{cm}^{3}$. The filtration coefficient of medium coarse sand and dusty sandy grit does not change, when the densities are $1,8 \mathrm{~g} / \mathrm{cm}^{3}, 1,9 \mathrm{~g} / \mathrm{cm}^{3}$.

\section{Determination of heavy metal concentrations}

Determination of heavy metals in leachate by Atomic Absorption Spectrometric (AAS) method

$1 l$ of leachate was filtrated through a glass filter into a $1000 \mathrm{ml}$ volumetric flask. $2 \mathrm{ml}$ of $\mathrm{HNO}_{3}$ were added into the leachate. As the concentrations of metals are lower than a measurable limit, the leachate must be concentrated. 11 of leachate was evaporating to $50 \mathrm{ml}$ and in the $50 \mathrm{ml}$ volumetric flask dilute to the mark with distilled water. Later the concentrations of heavy metals are measured by using a spectrometer Buck Scientific 210 VGP with an air-acetylene flame [9, 10].

\section{Concentration measurement}

The concentrations of metals are calculated by using the following equations [11]:

$$
\begin{gathered}
K=\frac{A}{C}, \\
C_{x}=\frac{A_{i s m}}{K},
\end{gathered}
$$

$$
C_{t i k r}=\frac{C_{x} \cdot 50}{1000}
$$

where

$K$ - coefficient;

$A$ - absorption (standards);

$C$ - coefficient (standards), $\mathrm{mg} / \mathrm{l}$;

$C_{x}$ - concentration measurement, $\mathrm{mg} / \mathrm{l}$;

$C_{t i k r}$ - true concentration, $\mathrm{mg} / \mathrm{l}$.

The results of the investigation are presented in Table 2.

Table 2. Concentrations of heavy metals

\begin{tabular}{|l|c|}
\hline \multicolumn{1}{|c|}{ Metals } & Investigation results \\
\hline Manganese & 0,122 \\
\hline Chromium & 0,29 \\
\hline Nickel & 0,39 \\
\hline Copper & 0,06716 \\
\hline Zinc & 0,044 \\
\hline Cobalt & 0,127 \\
\hline pH & 7,2 \\
\hline
\end{tabular}

\section{Simulation of heavy metal permeability in soils}

Leachate from the main landfill in Šiauliai region is collected in trenches. The width of a trench is about $2 \mathrm{~m}$, and the depth is about $1 \mathrm{~m}$.

According to this, we drew a contour, but the depth was chosen to be $5 \mathrm{~m}$ to control the permeability of the pollutants.

After determining the concentration of heavy metals and comparing the results with a permissible concentration range, we obtained that there was quite a large amount of nickel $(\mathrm{Ni})$, chromium $(\mathrm{Cr})$, cobalt $(\mathrm{Co})$ and manganese $(\mathrm{Mn})$ in the leachate. Their concentrations and ranges are given in Table 3.

According to the data of Table 3, we simulate the permeability of nickel, chromium, cobalt and manganese [12].

According to the created model and with the help of VS2DTI software [13, 14], the permeability of nickel in medium sand with a concentration of $0,4 \mathrm{mg} / \mathrm{l}$ was calculated. The results are shown in Fig 8.

As we can see in Fig 8, during all the 12 hours of calculation the pollutants dispersed on the surface, and the concentration reached $0,4 \mathrm{mg} / \mathrm{l}$. It means that this is 
Table 3. Comparison of heavy metal concentrations in landfill leachate and concentration range

\begin{tabular}{|l|c|c|}
\hline \multicolumn{1}{|c|}{ Metal } & $\begin{array}{c}\text { Experiment } \\
\text { results }\end{array}$ & $\begin{array}{c}\text { Concentration range (from } \\
\text { Robinson 1995), mg/l }\end{array}$ \\
\hline Nickel & 0,39 & $0,01-0,19$ \\
\hline Chromium & 0,29 & $0,01-0,17$ \\
\hline Cobalt & 0,127 & $<0,05$ \\
\hline Manganese & 0,122 & $0,01-0,16$ \\
\hline
\end{tabular}

a constant concentration of nickel on the soil surface. We can see weak lines on both sides of a trench; the concentration here is about $0,37 \mathrm{mg} / \mathrm{l}$. When the depth is more than $1 \mathrm{~m}$, the concentration decreases to $0,3 \mathrm{mg} / \mathrm{l}$. Then the nickel concentration decreases every $10 \mathrm{~cm}$. When the depth is $1,6 \mathrm{~m}$, the nickel concentration reaches the lowest permissible range $-0,01 \mathrm{mg} / \mathrm{l}$.

The next model was made and calculated for chromium, and its permeability in medium sand was shown. The results of calculation are given in Fig 9.

The results presented in Figs 8 and 9 are similar. When the depth is about $1 \mathrm{~m}$ from the trench bottom, the concentration of chromium remains the same $0,3 \mathrm{mg} / 1$. When the depth is about $1,5 \mathrm{~m}$ from the trench bottom, the concentration of chromium reaches the highest permissible value $-0,17 \mathrm{mg} / \mathrm{l}$, and a concentration of $0,01 \mathrm{mg} / \mathrm{l}$ is reached, when the depth is $2 \mathrm{~m}$. We have to take notice that such a distribution of the concentration was obtained in 12 hours, but in reality, when the pollution flow goes on for years, the concentration $C=0,3 \mathrm{mg} / \mathrm{l}$ must be considered to be much higher. Though our task was to show the permeability of pollutant characteristics in the soil, we can say that images in Figs 8 and 9 are identical, only the color scale of the concentration differs. That is why it would be logical, by simulating the permeability of pollutants into hard soils, to show only one concentration, either for nickel or chromium.

The concentrations of cobalt and manganese are very similar too, $0,13 \mathrm{mg} / \mathrm{l}$ and $0,12 \mathrm{mg} / \mathrm{l}$, accordingly. That is why the simulation results will also be similar. So illustration of the permeability of these pollutants into other soils it is logical to show the simulation results of either cobalt or manganese.

The permeability of cobalt in medium sand is given in Fig 10.

As it can be seen from the calculation results, cobalt leaks out to the surface. This means that the surface of the ground is always contaminated, and the concentration at that time is $0,13 \mathrm{mg} / 1$, when a permissible concentration should be less than $0,05 \mathrm{mg} / \mathrm{l}$. We can also see a slight change in colors between red and light red. It is lower than at the bottom of a trench, and in the figure of permeability of nickel and chromium this range is at the bottom of a trench.

Permeability in fine sand. In Fig 11 we can see the permeability of nickel, when its concentration is
$0,4 \mathrm{mg} / \mathrm{l}$. After the calculation of chromium permeability the concentration of which $(0,3 \mathrm{mg} / \mathrm{l})$ is very similar to that of nickel, we can see the same view, but the concentrations of pollutants slightly differ in colors. For this reason only the permeability of nickel in fine sand is shown. The results of the last calculations are very different from those achieved by analysing the permeability of heavy metals in medium sand. In this case pollutants spread vertically into the soil and just a little sideward. When it reaches a $4 \mathrm{~m}$ depth from the ground surface, the concentration of pollutants starts reducing gradually. As we can see in Fig 11, the trajectory of pollutant permeability is incurved into the opposite side from the direction of permeability. The trajectory of permeability of manganese and cobalt is very similar to that of nickel.

When a depth of $4 \mathrm{~m}$ from the surface is reached, we can see that a maximum concentration of manganese starts declining. According to the results of simulation, we can say that heavy metals penetrate into deeper layers of fine sand and almost do not penetrate into the Earth's surface.

Permeability in dusty sandy grit. Studying the filtration qualities of dusty sandy grit it is determined that the filtration coefficient of that soil is the lowest of all soils. It means that the results obtained during simulation would confirm this proposition. According to the model and after configuring equal conditions of permeability, we can see that heavy metals penetrate slower. The calculation results are given in Fig 12.

The obtained results affirmed the proposition. After 12 hours of calculation a maximum concentration of nickel continues to a depth of $2 \mathrm{~m}$ from the surface, i e it penetrates about $0,6 \mathrm{~m}$ from the source of pollution. Meanwhile, the same parameters of concentration are reached:

- $\quad$ according to analyses of medium sand, a maximum concentration starts declining at a depth of $1 \mathrm{~m}$ from the bottom of a trench;

- $\quad$ according to analyses of fine sand a maximum concentration starts declining at a depth of $2,5 \mathrm{~m}$ from the bottom of a trench.

As it was mentioned above, the concentrations of manganese and nickel differ slightly.

A maximum concentration of manganese starts declining at a depth of $0,6 \mathrm{~m}$ from the bottom of a trench. The characteristics of pollutant penetration are very similar to the permeability of heavy metals in medium sand, obviously, the penetration of dusty sandy grit is almost twice slower. But we have to pay attention that the leachate of a landfill has already been polluting the soil for several years, and heavy metals have possibly penetrated within a larger range. We should expect that in a longer period of time pollutants would reach the surface of the ground.

Permeability in silt loam. According to the created model, and when calculations were finished, we obtained the permeability of chromium in silt loam. The results are given in Fig 13. 


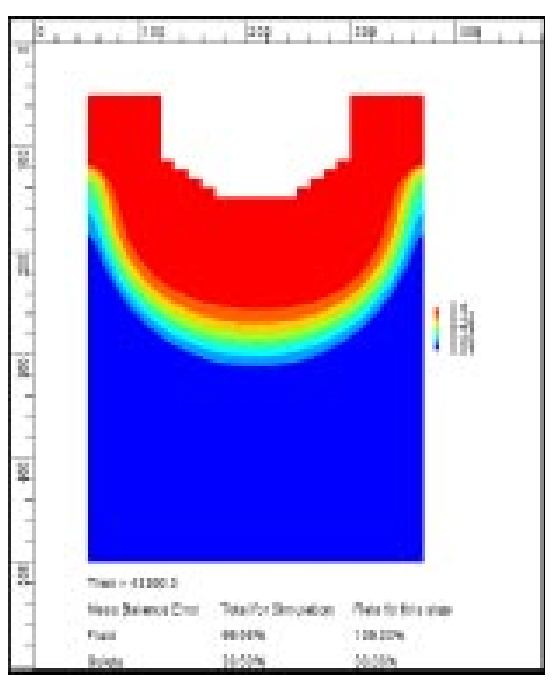

Fig 8. Permeability of nickel in medium sand

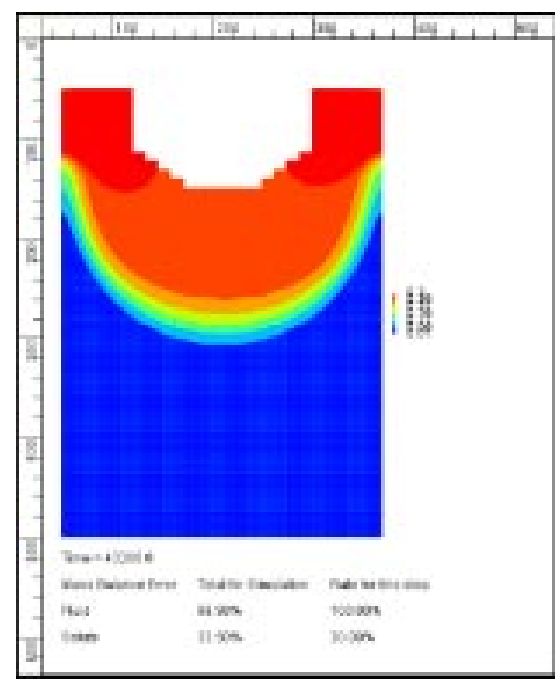

Fig 9. Permeability of chromium in medium sand

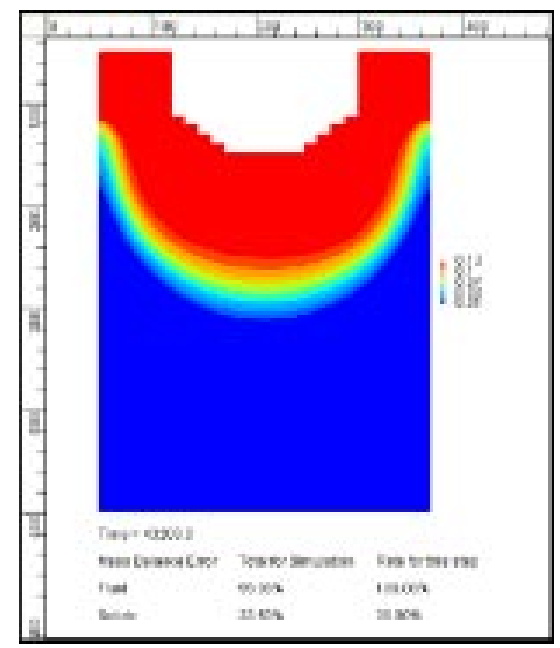

Fig 10. Permeability of cobalt in medium sand

This time the results of chromium are given. In Fig 13 we can see that the obtained results of simulation are very similar those with fine sand, however, in this case the permeability is significantly lower. Penetration

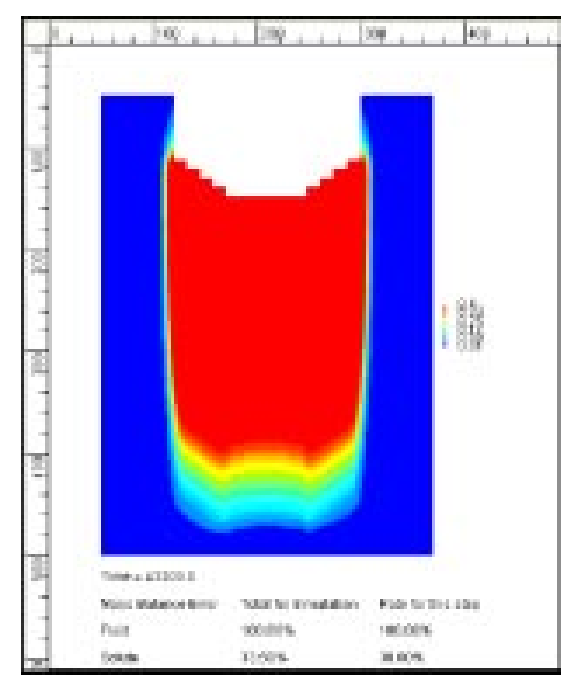

Fig 11. Permeability of nickel in fine sand

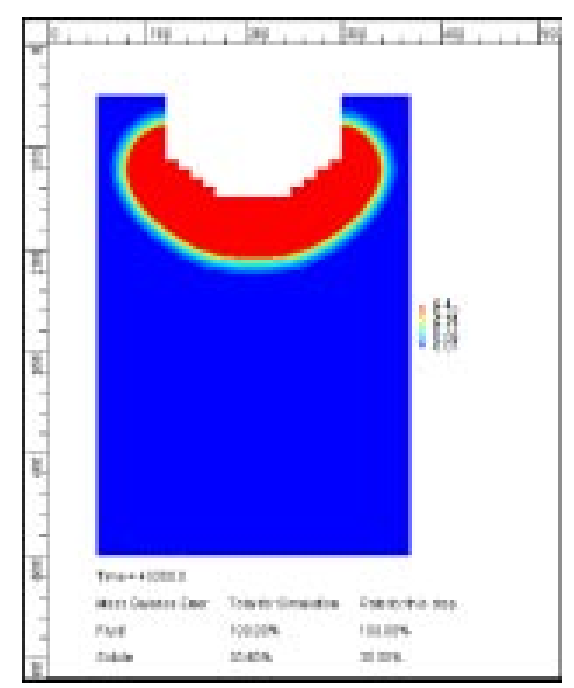

Fig 12. Permeability of nickel in dusty sandy grit

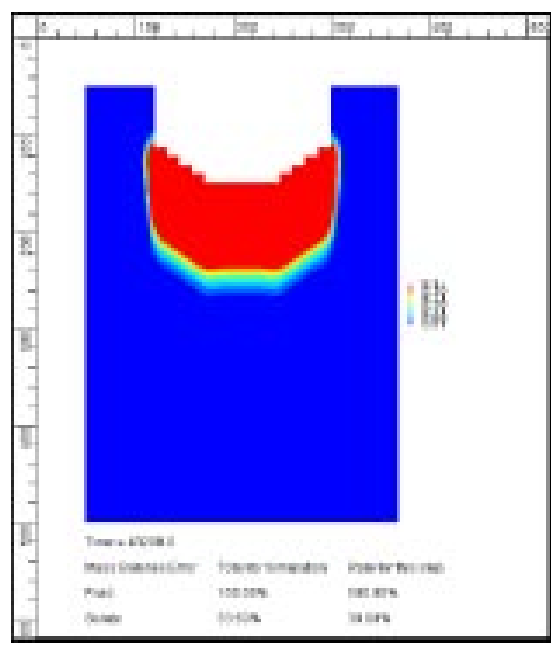

Fig 13. Permeability of chromium in silt loam

to the sides and upwards is quite slow. The main flow is directed towards depth. A maximum concentration starts declining at a depth of $0,9 \mathrm{~m}$ from the bottom of a trench.

The permeability of cobalt in silt loam is very simi- 
lar to that of chromium, but we should note that in both cases the interval of decline in pollutant concentrations is narrow compared with that of medium sand, and almost similar to the decline interval of dusty sandy grit concentration. The reason of that is a low filtration coefficient of these soils.

\section{Conclusions}

1. The results of the experiment confirm that the leachate generated in a landfill penetrates through the soil. The filtration coefficient of the soil depends on temperature and soil density.

2. The filtration coefficient of medium coarse sand at $15{ }^{\circ} \mathrm{C}$ is $0,886 \mathrm{~m} / 24 \mathrm{~h}$, and at $0{ }^{\circ} \mathrm{C}-0,806 \mathrm{~m} / 24 \mathrm{~h}$ (it reduced 1,1 times). The filtration coefficient of sand with organics, peat and fine sand at a temperature from $15^{\circ} \mathrm{C}$ to $0{ }^{\circ} \mathrm{C}$ decreased 1,3 times. The largest change of the filtration coefficient occurred in dusty sandy grit; it decreased 1,8 times.

3. In analyses of the experimental results on the filtration coefficient dependence upon density we can see that when density is $1,6 \mathrm{~g} / \mathrm{cm}^{3}$, the filtration coefficient (k) of medium coarse sand is $1,887 \mathrm{~m} / 24 \mathrm{~h}$, and when density is $1,9 \mathrm{~g} / \mathrm{cm}^{3}, k=0,311 \mathrm{~m} / 24 \mathrm{~h}$; it decreased 6 times. There was also a great change in peat. When its density was $0,6 \mathrm{~g} / \mathrm{cm}^{3}, k=6,197 \mathrm{~m} / 24 \mathrm{~h}$, and when its density was $0,9 \mathrm{~g} / \mathrm{cm}^{3}, k=1,960 \mathrm{~m} / 24 \mathrm{~h}$. The filtration coefficient reduced 3,2 times.

4. When the density of peat and sand with organics is the same and equal to $0,9 \mathrm{~g} / \mathrm{cm}^{3}$, the peat filtration coefficient $k=1,960 \mathrm{~m} / 24 \mathrm{~h}$, and the filtration coefficient of sand with organics $k=2,805 \mathrm{~m} / 24 \mathrm{~h}$. When the density is $1,6 \mathrm{~g} / \mathrm{cm}^{3}$, the filtration coefficient of fine sand $k=0,898 \mathrm{~m} / 24 \mathrm{~h}$, and for medium coarse sand $k=$ $1,887 \mathrm{~m} / 24 \mathrm{~h}$, that is 2,1 times larger. During the experiment we estimated the filtration coefficient of three soils at a density of $1,7 \mathrm{~g} / \mathrm{cm}^{3}$. These soils were dusty sandy grit, medium coarse sand and fine sand. Their filtration coefficient was: $0,688 \mathrm{~m} / 24 \mathrm{~h}, 0,886 \mathrm{~m} / 24 \mathrm{~h}, 0,765 \mathrm{~m} / 24 \mathrm{~h}$, accordingly. According to the results, we can assert that the filtration coefficient of these three soils is similar.

5. After the experiment we can assert that dusty sandy grit is the most suitable for landfill construction because dusty sandy grit has the lowest filtration coefficient $(0,262 \mathrm{~m} / 24 \mathrm{~h})$, when density is $2,0 \mathrm{~g} / \mathrm{cm}^{3}$.

6 . Heavy metals penetrate rather quickly into medium coarse sand although an assumption is made that pollutants are at the bottom of a trench. Heavy metals penetrate to the surface of the soil, and their concentration is constantly at a maximum there.

7. Pollutants spread vertically and just a little sideward into fine sand. The trajectory of pollutant permeability is incurved to the opposite side from the direction of permeability.

8. The characteristics of pollutant permeability in dusty sandy grit are very similar those of heavy metals in medium sand, and, obviously, the penetration of dusty sandy grit is much slower. But according to the fact that heavy metals penetrate into the soil year by year and according to the permeability characteristics, we can assert that a maximal concentration would be reached on the ground surface.

9. Similar situation is found in silt loam; the trajectory of permeability is similar to that of fine sand, and it is slower only 2,3 times.

10. Simulation of heavy metal permeability in soils has proved the main conclusions of the experiments that dusty sandy grit is the least permeable soil type.

\section{References}

1. Spruogis, J.; Jaskelevičius, B. Waste and its management. Schoolbook. Vilnius: Technika, 2000. 210 p. (in Lithuanian).

2. Wiley, J; and Sons inc. Design of Landfills and Integrated Solid Waste Management, 2003. 684 p.

3. Čygas, D.; Laurinavičius, A. Construction waste and feasibility study of its utilization for road construction in Lithuania. Journal of Environmental Engineering and Landscape Management, Vol XI, No 2, 2003, p 60-65.

4. Amšiejus, J.; Šimkus, J. Laboratory works of soils mechanics. Vilnius: VISI, 1989. 92 p. (in Lithuanian).

5. National standard of USSR. Soils. Methods of experimental filtration coefficient determination. ГОСТ 25584-90. 14 p. (in Russian).

6. Wilun, Z. Zarys geotehniki. Wydawnictwa Komunikaciji i Zącznošci. Warszawa, 1970. 691 p.

7. Lithuanian standard. Geotechnical. Classification and identification of soils. LST 1445:1996. 8 p. (in Lithuanian).

8. Hidrogeological manual. Moscow: Geotechizdat, 1962. 615 p. (in Russian).

9. International standard. Water quality - Determination of chromium - Atomic absorption spectrometric methods. Reference number: ISO 9174: 1998(E). 14 p.

10. International standard. Water quality - Determination of cobalt, nickel, copper, zinc, cadmium and lead - Flame atomic absorption spectrometric methods. Reference number: ISO 8288-1986 (E). 16 p.

11. Waste Management \& Research. The Journal of the International Solid Wastes and Public Cleansing Association ISWA. Vol 11, No 3, June 1993, 278 p.

12. The possibility of leachate quantity prediction on the base of selected municipal landfills in Poland. Bialystok University of Technology, Department of Environmental Protection, Wiejska 45 A, 15-351 Białystok. 3 p.

13. Hsieh, P. A.; Wingle, W.; Healy, R. W. VS2DTI - A Graphical User Interface for the Variably Saturated Flow and Solute Transport Computer Program VS2DT, 1999. $17 \mathrm{p}$.

14. VS2DTI software user guide. Help for VS2DTI - Version 1.1. $50 \mathrm{p}$. 


\title{
SĄVARTYNO FILTRATO SKVARBOS DIRVOŽEMYJE TYRIMAI IR ĮVERTINIMAS
}

S. Vasarevičius, J. Čegariova, D. Sližytė

\author{
$\mathrm{S}$ a n tra $\mathrm{u} \mathrm{k}$ a
}

Šiandien viena iš svarbiausių aplinkosauginių problemų yra atliekų tvarkymas, grèsmę keliantys seni sąvartynai bei juose susikaupęs filtratas.

Eksperimentų tikslas buvo atlikti sąvartyno filtrato skvarbos eksperimentinius tyrimus, ịvertinti filtrate esančių sunkiujjų metalų koncentracijas ir sumodeliuoti jų sklaidą dirvožemiuose.

Eksperimentas atliktas su gruntais, būdingais sąvartynų vietovėms. Filtrato imta iš Šiauliu regiono Kairiu sąvartyno filtrato surinkimo griovio. KF-OOM įrenginiu buvo nustatyti skirtingo tankio gruntų filtracijos koeficientai, esant skirtingoms oro sąlygoms. Taikant liepsnos absorbcijos spektrometrijos metodą, apskaičiuotos sunkiujų metalų koncentracijos filtrate. Šiaulių regiono pagrindinio sąvartyno (Kairiai) filtratas yra surenkamas i griovius. Nustačius sunkiujjų metalų koncentracijas filtrate gaunama, kad mangano, chromo, nikelio ir kobalto koncentracijos yra gana didelès, palyginti su kitų sąvartynų filtrato sudètimi. Didžiausias filtrate yra nikelio kiekis - 0,39 mg/l. Pagal gautas koncentracijas VS2DTI programa buvo sumodeliuotas sunkiujų metalų skverbimosi dirvožemyje pobūdis. Skirtinguose gruntuose jis yra skirtingas.

Atlikus eksperimentinius tyrimus bei sunkiujų metalų sklaidos modeliavimą, nustatyta, kad mažiausiai laidus filtratui bei teršalams gruntas yra dulkingas smèlingas žvyras.

Raktažodžiai: sąvartynas, filtratas, fltracijos koeficientas, atominès absorbcinès spektrofotometrijos metodas.

Saulius VASAREVIČIUS. Dr, Assoc Prof (since 1999), senior research worker, Institute of Environmental Protection, Vilnius Gediminas Technical University (VGTU).

Doctor of Science (environmental engineering), VTU (now VGTU), 1995. Master of Science, VTU, 1991. First degree in Civil Engineering and Management, Vilnius Civil Engineering Institute (VISI, now VGTU), 1989 Publications: author of more than 30 research papers and monographs. Probation in Germany. Research interests: environmental management, air pollution, waste management.

Jelena ČEGARIOVA. Master student, Dept of Environmental Protection, Vilnius Gediminas Technical University (VGTU). Bachelor of Science (environmental engineering), VGTU, 2003. Research interests: environmental management, waste management.

Danutė SLIŽYTĖ: Dr, Assoc Prof, Dept of Geotechnical Engineering, Vilnius Gediminas Technical University (VGTU). Doctor of Science (technological sciences), 2001. Master of Science (construction engineering), VGTU, 1996. First degree in Civil Engineering, VTU (now VGTU), 1994.

Publications: author of more than 10 research papers. Research interests: soil classification, reinforcement wall and polar foundation design methods. 